Hybrid CONSTITUTIONS 



\section{Hybrid CONSTITUTIONS}

Challenging Legacies of

Law, Privilege, and Culture

in Colonial America

VICKI HSUEH

Duke University Press

Durham and London 2010 
(C) 2010 Duke University Press

All rights reserved

Printed in the United States of America on acid-free paper $\infty$ Designed by Heather Hensley

Typeset in Minion Pro by Achorn International, Inc.

Library of Congress Cataloging-in-Publication Data appear on the last printed page of this book.

Duke University Press gratefully acknowledges the support of Western Washington University, which provided funds toward the production of this book. 